\title{
Analysis of the effect of dietary protected organic acid blend on lactating sows and their piglets
}

\author{
Subramaniam Mohana Devi ${ }^{1}$, Kwang Yong Lee ${ }^{1}$, In Ho Kim ${ }^{1}$
}

${ }^{1}$ Dankook University, Department of Animal Resource \& Science, Cheonan, Chungnam, South Korea.

\begin{abstract}
The objective of the present study was to evaluate the effects of blends of dietary protected organic acid supplementation on growth performance, nutrient digestibility, blood profiles, faecal microflora, and gas emission on sows and piglets with emphasis on their modes of action to improve pig performance. A total of 12 sows with an average initial body weight (BW) of $252.40 \pm 11.7 \mathrm{~kg}$ were used in this trial. Growth performance, blood profiles, and nutrient digestibility of sows and piglets fed protected organic acid were evaluated. The dietary treatments included a basal diet (CON); CON $+0.1 \%$ protected organic acid; and $\mathrm{CON}+0.2 \%$ protected organic acid. The BW and back fat of sows was checked four days prior to farrowing and at the weaning day to calculate BW loss and back fat loss during that period. Inclusion of $0.2 \%$ protected organic acid provided a greater digestibility than CON diets throughout the experimental period in lactating sows. Dietary supplementation with $0.2 \%$ protected organic acid led to a higher white blood cell and lymphocyte concentration than $\mathrm{CON}$ treatment in sucking piglets. Immunoglobulin $\mathrm{G}$ concentration observed was greater in protected organic acid groups in lactating sow and sucking piglets. Increased faecal Lactobacillus counts with decreased E. coli concentrations were observed with the diets of protected organic acid fed to lactating sows. The E. coli counts were decreased in weaning piglets. The faecal $\mathrm{H}_{2} \mathrm{~S}$ contents were decreased in $0.2 \%$ protected organic acid diets during farrowing on day 1 . Dietary supplementation with protected organic acid blends beneficially affects the nutrient digestibility, ileal noxious gas $\left(\mathrm{NH}_{3}\right.$ and $\left.\mathrm{H}_{2} \mathrm{~S}\right)$ emission, as well as intestinal microbial balance in lactating sows.
\end{abstract}

Key Words: blood profiles, digestibility, growth performance, noxious gas, pigs

\section{Introduction}

Supplementation of pig diets with organic acids has become an important nutritional strategy aimed at improvement, performance, and health status of animals fed diets devoid of antibacterial growth promoters. Positive effects of acids are associated mainly with increased gastric acidity, antibacterial activity, reduced coliform populations, and improved digestibility (Jensen et al., 2003).

Studies prior to 2006 indicate that health strategies widely used antibiotic growth promoters to reduce enteric infections and the occurrence of pathogens able to adhere to intestinal mucosa (Budino et al., 2005). Among a variety of candidates for the replacement of antibiotics, organic acids have been broadly applied worldwide with reasonable success (Mroz, 2005). The successful use of organic acids in the diets of pigs requires understanding of their mechanisms of action. Organic acids may influence the physiology of the

Received June 25, 2015 and accepted November 5, 2015.

Corresponding author: inhokim@dankook.ac.kr

http://dx.doi.org/10.1590/S1806-92902016000200001

Copyright (c) 2016 Sociedade Brasileira de Zootecnia. This is an Open Access article distributed under the terms of the Creative Commons Attribution License (http://creativecommons.org/licenses/by/4.0/), which permits unrestricted use, distribution, and reproduction in any medium, provided the original work is properly cited. intestinal mucosa by their action on the villi, maintaining their integrity, promoting an increase in the number of cells and preventing its flattening, as well as serving as a substrate in the intermediary metabolism of the citric acidcycle (Partanen and Mroz, 1999). Organic acids can also reduce the diets' buffering capacity, inhibit the proliferation and colonisation of undesirable microorganisms, act on the physiology of the gastrointestinal mucosa, and promote the availability of nutrients in the diet, improving their digestion, absorption, and retention (Costa et al., 2011). In some countries, organic acids are used to decontaminate microorganisms in feed ingredients (Koyuncu et al., 2013). According to Overland et al. (2008), dietary inclusions of organic acids have positive effects in improving growth rate and feed efficiency. A combination of organic acids would enhance the effectiveness of acidification and maintains optimum pH (Ravindran and Kornegay, 1993). Our previous study suggested that inclusion of bacteriophages could be used as an antibiotics alternative for growing pigs (Yan et al., 2012). However, the effectiveness varies with the types and combinations of acid, the health status of the animal, and feed characteristics (Mroz et al., 2006). The protected organic acid used in the current study is a blend of organic acids and medium-chain fatty acids (MCFA) with matrix coating. 
Protected organic acids and MCFA are released in the small intestine by lipase and those undissociated organic acids released inhibit the growth of hazardous bacteria (Salmonella and E. coli, etc.) and increase the population of desired bacteria (lactic acid bacteria). The protective lipid matrix used for microencapsulation of the organic acid blend allowed slow-release of the active ingredients, preventing the immediate disappearance of such compounds upon exiting the stomach. The longer permanence along the gastrointestinal tract of active compounds allowed them to act synergistically on the intestinal microflora and to reduce coliform counts.

In the present study, the protected organic acid consists of MCFA for animal nutrition and metabolism, especially made by technology of Joint Matrix coating. Therefore, we hypothesised that the blends of different organic acids with MCFA in matrix coating could play an influential role in improving growth performance, microbial population, nutrient digestibility, blood profiles and gas emission of lactating sows and their piglets. The objective of the present study was to evaluate the effects of blends of dietary protected organic acid supplementation on growth performance, nutrient digestibility, blood profiles, faecal microflora, and gas emission in sows and piglets with emphasis on their modes of action to improve pig performance.

\section{Material and Methods}

The study was carried out following the procedures approved by the Animal Care and Use Committee of Dankook University, in Cheonan, Chungnam, South Korea, for experiments with animals.

The matrix coated organic acid used in the current experiment was provided by a commercial company (Morningbio Co., Ltd., Cheonan, Korea). This protected organic acid consists of MCFA and composite organic acids. The active ingredients were 17\% fumaric acid, 13\% citric acid, 10\% malic acid, 1.2\% MCFA (capric and caprylic acids), and a carrier.

A total of 12 crossed (Landrace $\times$ Yorkshire) sows and 120 piglets from Dankook University experimental farm were used in this current study to investigate the effect of protected organic acid on the production performance of sows and piglets. Pigs were randomly allocated into one of three treatments (four replications) in a randomized complete block design. The pigs were cross-fostered after farrowing to ten piglets per sow. Dietary treatments included: a basal diet $(\mathrm{CON}) ; \mathrm{CON}+0.1 \%$ protected organic acid; and $\mathrm{CON}+0.2 \%$ protected organic acid. Sows were fed a same commercial gestation diet from 28 to 95 days of lactation. After 95 days, the gestating sows were fed the experimental diet. The farrowing parity of experimental sows consisted of four sows for each treatment. The diets (Table 1) were formulated to meet or exceed the nutrient requirements recommended by NRC (2012). The farrowing crate $(2.1 \times 0.6 \mathrm{~m})$ contained an air-conditioned area for newborn pigs on each side, and the temperature in the farrowing house was maintained at a minimum of $20^{\circ} \mathrm{C}$ with supplemental heat provided by heat lamps. Piglets were treated according to routine management practices that included teeth clipping, tail docking, and ear tagging for labelling, and received injections of $1 \mathrm{~mL}$ of iron dextran and males were castrated five days after birth. After farrowing, sows received $1 \mathrm{~kg}$ of standard lactation diet and increased feed by $1 \mathrm{~kg}$ each day ad libitum to avoid overconsumption. All diets were provided in meal form, and sows were provided with free access to drinking water throughout the experimental period.

Sows were weighed at the start of the experiment, before farrowing, after farrowing, and at the weaning period. The initial treatment was the experimental diet. The back fat thickness and body weight of the sows were measured within a few hours after the start of the experiment, at farrowing, and at weaning (21 days). The daily feed intake of the sows

Table 1 - Composition of experimental diets (as-fed basis)

\begin{tabular}{|c|c|}
\hline Item & Lactation diet \\
\hline \multicolumn{2}{|l|}{ Ingredient, $\mathrm{g} / \mathrm{kg}$} \\
\hline Ground maize & 510.0 \\
\hline Soybean meal (480 g/kg CP) & 267.3 \\
\hline Wheat bran & 10.0 \\
\hline Rice bran & 50.0 \\
\hline Rapeseed meal (430 g/kg CP) & 35.0 \\
\hline Tallow & 60.5 \\
\hline Molasses & 35.0 \\
\hline Dicalcium phosphate & 16.4 \\
\hline Limestone & 7.6 \\
\hline $\mathrm{NaCl}$ & 5.0 \\
\hline L-lysine-HCl (780 g/kg) & 1.2 \\
\hline Vitamin premix $^{1}$ & 1.0 \\
\hline Trace mineral premix ${ }^{2}$ & 1.0 \\
\hline \multicolumn{2}{|l|}{ Analysed nutrient content, $\mathrm{g} / \mathrm{kg}$} \\
\hline Dry matter & 888.7 \\
\hline Metabolisable energy, $\mathrm{MJ} / \mathrm{kg}$ & 14.47 \\
\hline Crude protein & 183.4 \\
\hline Crude fat & 91.6 \\
\hline Lysine & 10.8 \\
\hline Calcium & 10.6 \\
\hline Total phosphorus & 7.3 \\
\hline Iron, $\mathrm{mg} / \mathrm{kg}$ & 25.0 \\
\hline \multicolumn{2}{|c|}{ 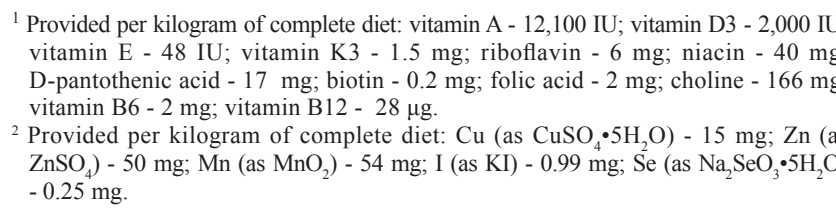 } \\
\hline
\end{tabular}


was determined as the difference between feed allowance and the refusals collected after feeding. After farrowing, piglets were ear-notched and weighed individually. Individual piglet body weight (BW) was assessed on days $0,7,14$, and 21 (weaning), whereas the number of piglets of every sow was recorded on farrowing day and weaning day to evaluate the survival rate of piglets. The back fat thickness $(6 \mathrm{~cm}$ of the midline at the 10th rib) measurements were taken using a real-time ultrasound instrument (Piglot 105, SFK Technology, Herlec, Denmark).

Chromium oxide was added to all the diets at $2 \mathrm{~g} / \mathrm{kg}$ as an indigestible marker for determination of apparent total tract digestibility of dry matter (DM), nitrogen $(\mathrm{N})$, and gross energy (Ball and Aherne, 1987). On days 26, 27 , and 28 , faecal samples were collected from all pigs in each pen in the afternoon via rectal massage and pooled within pen. Faecal samples (four samples per treatment) and feed samples were stored in a freezer at $-20{ }^{\circ} \mathrm{C}$ until further analysis. For chemical analysis, faecal and feed samples were freeze-dried and ground to pass through a 1-mm screen. Dietary DM, calcium, phosphorus, crude protein, lysine, and methionine were analysed according to the procedures described by AOAC (2000). Chromium was analysed by UV absorption spectrophotometry (Shimadzu, UV-1201, Kyoto, Japan) (Williams et al., 1962), and N was measured using a Kjeltec 2300 analyser (Foss Tecator AB, Hoeganaes, Sweden). Gross energy was determined using a Parr 6100 Oxygen Bomb Calorimeter (Parr Instrument Co., Moline, IL, USA). The apparent total tract digestibility of DM, $\mathrm{N}$ and gross energy were calculated using indirect methods as described by Zhao et al. (2012).

The incidence of diarrhoea in piglets was observed and recorded from five days after farrowing to weaning every day. To assess the severity of diarrhoea, faeces from each pig were scored by determining the moisture content according to the method described by Hart and Dobb (1988). In short, scores were 0 for normal, firm faeces; 1 for possible slight diarrhoea; 2 indicated definitely unformed, moderately fluid faeces; or 3 in case of very watery and frothy diarrhoea. A cumulative diarrhoea score per diet and day was further assessed (Montagne et al., 2004).

Blood from sows was collected via vena cava puncture before feeding at farrowing and weaning (21 days) whereas six piglets per treatment were selected randomly at weaning. Blood from the same sows and piglets were collected on day 21. Blood samples were collected into 5 -mL vacuum tubes with $\mathrm{K}_{3}$ EDTA (Becton Dickinson Vacutainer Systems, Franklin Lakes, NJ, USA) and placed on ice until analysis. The concentration of white blood cells (WBC) and lymphocyte in the whole blood samples were determined using an automatic blood analyser (ADVIA 120, Bayer, Tarry town, NY, US). Whole blood samples were subsequently centrifuged for $15 \mathrm{~min}$ at $3000 \times \mathrm{g}$ at $4{ }^{\circ} \mathrm{C}$ and the harvested serum was used to determine blood profiles. Serum immunoglobulin G (IgG) was particularly analysed using nephelometry (Dade Behring, Marburg, Germany).

On farrowing and weaning, faecal samples (for individual sows) were collected by rectal massage from all sows from each pen, pooled, and transported to the lab for immediate analysis. One gram of the composite faecal sample from each pen was diluted with $9 \mathrm{~mL}$ of $1 \%$ peptone broth (Becton, Dickinson and Co., Franklin Lakes, USA) and homogenised. Viable counts of bacteria in the faecal samples were then conducted by plating serial 10 -fold dilutions (in $1 \%$ peptone solution) onto MacConkey agar plates (Difco Laboratories, Detroit, MI, USA) and Lactobacilli spp. medium III agar plates (Medium 638, DSMZ, Braunschweig, Germany) to isolate the Escherichia coli and Lactobacillus, respectively. The Lactobacilli medium III agar plates were then incubated for $48 \mathrm{~h}$ at $39^{\circ} \mathrm{C}$ under anaerobic conditions and the MacConkey agar plates were incubated for $24 \mathrm{~h}$ at $37^{\circ} \mathrm{C}$ and counted.

At the end of farrowing and weaning, faecal $\mathrm{NH}_{3}, \mathrm{R} . \mathrm{SH}$, $\mathrm{H}_{2} \mathrm{~S}$, and acetic acid concentrations were determined using the methods described by Yan and Kim (2013). A total of $300 \mathrm{~g}$ fresh faecal samples were collected from at least two pigs in each pen (14 pigs per treatment), then transferred to a sealed box and fermented for $48 \mathrm{~h}$ at $32{ }^{\circ} \mathrm{C}$ in an incubator. At day 5, levels of $\mathrm{NH}_{3}, \mathrm{R} . \mathrm{SH}, \mathrm{H}_{2} \mathrm{~S}$, and acetic acid were measured within the range of 5.0-100.0 (No. 3La, detector tube; Gastec Corp.), 2.0-20.0 (4LK, detector tube; Gastec Corp.), 0.5-120.0 (No.70 L and 70, detector tube; Gastec Corp.), and 2.0-50.0 (No.81 L, detector tube; Gastec Corp.) ppm. Prior to the measurements, slurry samples were shaken manually for approximately $30 \mathrm{~s}$ to disrupt any crust formation on the surface and homogenised. Adhesive plasters were punctured, and $100 \mathrm{~mL}$ of headspace air were sampled, approximately $2.0 \mathrm{~cm}$ above the slurry surface. Two samples from each pen were measured and then the average was calculated.

Data were subjected to general linear model (GLM) procedure of SAS (Statistical Analysis System, version 7.0) in a randomised complete block design. Effects of treatments (Control; $\mathrm{CON}+0.1 \%$ protected organic acid; and CON $+0.2 \%$ protected organic acid) were analysed by ANOVA for assessing the design, and linear and quadratic effects of each treatment. Results are presented as least square mean and the variability in data was expressed as standard error of the mean (SEM). Before conducting statistical 
analysis of the microbial counts, the value was transformed logarithmically. Linear and quadratic polynomial contrasts were performed to determine the effects of inclusion level of $0.1 \%$ and $0.2 \%$ protected organic acid blends in the diet. Probability values higher than or equal to 0.05 were considered significant.

\section{Results}

There was no significant difference $(\mathrm{P}>0.05)$ in before farrowing, after farrowing, and weaning body weight of sows (Table 2), and nor did the sow body weight loss differ in the dietary treatments $(\mathrm{P}>0.05)$ during the lactating period. No difference $(\mathrm{P}>0.05)$ was observed in ADFI and back fat thickness loss during the experiments. Piglet survival was not affected by dietary treatments, birth weight (1-week weight, 2-week weight, weaning weight), or ADG (Table 3, $\mathrm{P}>0.05)$. The number of diarrhoeal piglets and faecal score showed no difference $(\mathrm{P}>0.05)$ in suckling piglets during the experimental period (Table 4). During the experimental period, digestibility of DM, N, and energy was found to increase linearly by the dietary supplementation of $0.2 \%$ protected organic acid diets (Table 5; $\mathrm{P}<0.01$ ).

No difference $(\mathrm{P}>0.05)$ was observed in $\mathrm{WBC}$, lymphocyte, and $\mathrm{IgG}$ in farrowing sows. The $\mathrm{WBC}$ and

Table 2 - Effect of dietary protected organic acid blend supplementation on performance in lactating sows ${ }^{1}$

\begin{tabular}{|c|c|c|c|c|c|c|}
\hline Item & $\mathrm{CON}$ & POA1 & POA2 & $\mathrm{SE}$ & Linear $^{2}$ & Quadratic $^{2}$ \\
\hline Parity & 4 & 4 & 4 & & & \\
\hline \multicolumn{7}{|l|}{ Litter } \\
\hline Number of pigs & 11.8 & 13.0 & 11.0 & 1.4 & 0.8 & 0.5 \\
\hline Weaned pigs & 9.3 & 11.0 & 9.8 & 1.2 & 0.9 & 0.5 \\
\hline \multicolumn{7}{|l|}{ Body weight, kg } \\
\hline Before farrowing ${ }^{3}$ & 267.0 & 274.2 & 275.6 & 10.0 & 0.6 & 0.8 \\
\hline After farrowing & 245.9 & 253.5 & 252.8 & 10.1 & 0.6 & 0.7 \\
\hline Weaning & 236.9 & 245.4 & 245.5 & 10.2 & 0.6 & 0.7 \\
\hline Body weight loss ${ }^{4}$ & 9.0 & 8.0 & 7.3 & 0.9 & 0.3 & 0.9 \\
\hline \multicolumn{7}{|l|}{ ADFI, $\mathrm{kg}$} \\
\hline 1 week & 4.14 & 4.31 & 4.33 & 0.19 & 0.5 & 0.8 \\
\hline 2 week & 6.23 & 5.98 & 6.35 & 0.66 & 0.9 & 0.7 \\
\hline 3 week & 7.25 & 7.51 & 7.19 & 0.37 & 0.9 & 0.5 \\
\hline Overall & 5.85 & 5.93 & 5.90 & 0.32 & 0.9 & 0.9 \\
\hline \multicolumn{7}{|l|}{ Backfat thickness, mm } \\
\hline Before farrowing ${ }^{3}$ & 19.3 & 19.3 & 20.9 & 1.0 & 0.3 & 0.5 \\
\hline After farrowing & 17.0 & 18.1 & 18.3 & 1.0 & 0.4 & 0.7 \\
\hline Weaning & 14.8 & 17.1 & 17.5 & 1.4 & 0.2 & 0.5 \\
\hline Backfat thickness $\operatorname{loss}^{5}$ & 2.3 & 1.0 & 1.6 & 0.7 & 0.5 & 0.2 \\
\hline Oestrus interval, d & 4.0 & 3.5 & 3.8 & 0.4 & 0.6 & 0.4 \\
\hline \multicolumn{7}{|c|}{$\begin{array}{l}\text { ADFI - average daily feed intake; SE - standard error. } \\
{ }^{1} \text { CON - basal diet; POA } 1=\mathrm{CON}+0.1 \% \text { POA; POA2 } \\
{ }^{2} \text { CON vs. POA } 1 \text { vs. POA } 2 \text {. } \\
{ }^{3} \text { Farrowing before } 4 \text { days. } \\
{ }^{4} \text { Body weight loss from farrowing to weaning. } \\
{ }^{5} \text { Backfat thickness loss from farrowing to weaning. }\end{array}$} \\
\hline
\end{tabular}

lymphocyte of $0.2 \%$ protected organic acid were increased (linear effect, $\mathrm{P}=0.003$ ) after sow weaning. Moreover, the IgG concentration of protected organic acid increased (linear effect, $\mathrm{P}<0.001$ ) after sow weaning. Besides, IgG concentration was higher (linear effect, $\mathrm{P}<0.001$ ) in the groups fed protected organic acid diets (Table 6). Supplementation of $0.2 \%$ protected organic acid diet to sucking piglets (Table 6) provided greater (linear effect, $\mathrm{P}=0.01)$ WBC counts than CON diet.

Table 3 - Effect of dietary protected organic acid blend supplementation on performance in suckling piglets ${ }^{1}$

\begin{tabular}{lcccccc}
\hline Item & CON & POA1 & POA2 & SE & Linear $^{2}$ & Quadratic $^{2}$ \\
\hline Piglet survival, \% & 94.4 & 96.9 & 97.2 & 3.1 & 0.5 & 0.8 \\
Body weight, kg & & & & & & \\
$\quad$ Birth weight & 1.52 & 1.56 & 1.69 & 0.14 & 0.4 & 0.8 \\
1-week weight & 2.96 & 2.94 & 3.04 & 0.17 & 0.8 & 0.8 \\
2-week weight & 4.74 & 4.83 & 4.89 & 0.23 & 0.7 & 1.0 \\
Weaning weight & 6.70 & 6.86 & 6.96 & 0.39 & 0.6 & 1.0 \\
Average daily gain, g & & & & & & \\
1 week & 202 & 193 & 190 & 8 & 0.4 & 0.8 \\
2 week & 255 & 270 & 265 & 16 & 0.6 & 0.6 \\
3 week & 280 & 289 & 295 & 30 & 0.7 & 1.0 \\
Overall & 246 & 251 & 250 & 15 & 0.8 & 0.9 \\
\hline
\end{tabular}

SE - standard error.

${ }^{1} \mathrm{CON}$ - basal diet; POA $1=\mathrm{CON}+0.1 \% \mathrm{POA}$; POA2 $=\mathrm{CON}+0.2 \% \mathrm{POA}$ ${ }^{2} \mathrm{CON}$ vs. POA1 vs. POA2

Table 4 - Effect of protected organic acid blend supplementation on faecal score in suckling piglets ${ }^{1}$

\begin{tabular}{|c|c|c|c|c|c|c|}
\hline Item & $\mathrm{CON}$ & POA1 & POA2 & SE & Linear $^{2}$ & Quadratic $^{2}$ \\
\hline \multicolumn{7}{|l|}{ Farrowing } \\
\hline Number of piglets & 1.5 & 1.0 & 0.8 & 0.3 & 0.3 & 0.8 \\
\hline Faecal score $^{3}$ & 3.4 & 3.3 & 3.3 & 0.2 & 0.6 & 0.8 \\
\hline \multicolumn{7}{|l|}{ Weaning } \\
\hline Number of piglets & 0.5 & 0.3 & 0.0 & 0.3 & 0.1 & 1.0 \\
\hline Faecal score ${ }^{3}$ & 3.3 & 3.1 & 3.0 & 0.1 & 0.1 & 1.0 \\
\hline \multicolumn{7}{|c|}{$\begin{array}{l}\text { SE - standard error. } \\
{ }^{1} \text { CON - basal diet; POA } 1=\mathrm{CON}+0.1 \% \mathrm{POA} ; \mathrm{POA} 2=\mathrm{CON}+0.2 \% \mathrm{POA} . \\
{ }^{2} \mathrm{CON} \text { vs. POA } 1 \text { vs. POA2. } \\
{ }^{3} \text { Faecal score: } 1 \text { - hard, dry pellets in a small, hard mass; } 2 \text { - hard, formed stool that } \\
\text { remains firm and soft; } 3 \text { - soft, formed, and moist stool that retains its shape; } \\
4 \text { - soft, unformed stool that assumes the shape of the container; } 5 \text { - watery, liquid } \\
\text { stool that can be poured. }\end{array}$} \\
\hline
\end{tabular}

Table 5 - Effect of dietary protected organic acid blend supplementation on nutrient digestibility in lactating sows ${ }^{1}$

\begin{tabular}{lcccccc}
\hline Item, \% & CON & POA1 & POA2 & SE & Linear $^{2}$ & Quadratic $^{2}$ \\
\hline Weaning & & & & & & \\
Dry matter & $65.20 \mathrm{~b}$ & $67.08 \mathrm{ab}$ & $68.30 \mathrm{a}$ & 0.70 & 0.005 & 0.69 \\
Nitrogen & $70.17 \mathrm{~b}$ & $72.05 \mathrm{ab}$ & $73.56 \mathrm{a}$ & 0.94 & 0.02 & 0.87 \\
Energy & $65.39 \mathrm{~b}$ & $66.49 \mathrm{ab}$ & $69.16 \mathrm{a}$ & 0.92 & 0.008 & 0.50 \\
\hline
\end{tabular}

$\mathrm{SE}$ - standard error.

${ }^{1} \mathrm{CON}$ - basal diet; $\mathrm{POA} 1=\mathrm{CON}+0.1 \% \mathrm{POA} ; \mathrm{POA} 2=\mathrm{CON}+0.2 \% \mathrm{POA}$.

${ }^{2} \mathrm{CON}$ vs. POA1 vs. POA2.

$\mathrm{a}, \mathrm{b}$ - means in the same row with different letters differ $(\mathrm{P}<0.05)$. 
Sows fed protected organic acid diets had lower (linear effect, $\mathrm{P}<0.05) E$. coli contents in the farrowing and weaning periods compared with sows fed the CON diet (Table 7). In addition, protected organic acid treatments lead to a higher (linear effect, $\mathrm{P}<0.04$ ) Lactobacillus concentration in the farrowing and weaning periods (Table 7). Results for faecal gas emission of sows (Table 8) indicated the protected organic acid treatment provided a lower (linear effect, $\mathrm{P}=0.01) \mathrm{H}_{2} \mathrm{~S}$ than non-protected organic acid treatment at the end of farrowing. Moreover, supplementation of protected organic acid resulted in lower (linear effect, $\mathrm{P}<0.04) \mathrm{NH}_{3}$ levels compared with that of CON treatment on days 1 and 5 .

\section{Discussion}

Livestock production can make good use of resources, which contributes with high-quality nutrients to the human diet (Mohana Devi et al., 2014a). Organic acids are widely distributed in plants and animals produced by microbial

Table 6 - Effect of dietary protected organic acid blend supplementation on blood profiles in lactating sows and suckling piglets ${ }^{1}$

\begin{tabular}{|c|c|c|c|c|c|c|}
\hline Item, $\log _{10} \mathrm{cfu} / \mathrm{g}$ & $\mathrm{CON}$ & POA1 & POA2 & $\mathrm{SE}$ & Linear $^{2}$ & Quadratic $^{2}$ \\
\hline \multicolumn{7}{|l|}{ Farrowing } \\
\hline $\mathrm{WBC}, 10^{3} / \mu \mathrm{L}$ & 10.52 & 11.01 & 11.32 & 0.89 & 0.54 & 0.94 \\
\hline Lymphocyte, \% & 19.05 & 20.90 & 19.68 & 2.75 & 0.88 & 0.66 \\
\hline $\mathrm{IgG}, \mathrm{mg} / \mathrm{dL}$ & 833 & 873 & 866 & 31 & 0.47 & 0.55 \\
\hline \multicolumn{7}{|l|}{ Weaning } \\
\hline $\mathrm{WBC}, 10^{3} / \mu \mathrm{L}$ & $10.07 b$ & $12.07 \mathrm{ab}$ & $14.60 \mathrm{a}$ & 0.75 & 0.003 & 0.90 \\
\hline Lymphocyte, \% & $43.1 b$ & 44.0ab & $46.0 \mathrm{a}$ & 0.7 & 0.01 & 0.54 \\
\hline $\mathrm{IgG}, \mathrm{mg} / \mathrm{dL}$ & $815 b$ & $1,383 a$ & $1,300 \mathrm{a}$ & 43 & $<0.0001$ & 0.0002 \\
\hline \multicolumn{7}{|l|}{ Suckling } \\
\hline $\mathrm{WBC}, 10^{3} / \mu \mathrm{L}$ & $9.75 b$ & $11.06 \mathrm{ab}$ & $11.88 \mathrm{a}$ & 0.56 & 0.01 & 0.72 \\
\hline Lymphocyte, \% & 48.1 & 54.4 & 51.2 & 2.2 & 0.34 & 0.09 \\
\hline $\mathrm{IgG}, \mathrm{mg} / \mathrm{dL}$ & $273 b$ & $382 \mathrm{a}$ & $375 a$ & 15 & $<0.0001$ & 0.003 \\
\hline
\end{tabular}

Table 7 - Effect of dietary protected organic acid blend supplementation on faecal microflora in lactating sows $^{1}$

\begin{tabular}{lcccccc}
\hline Item, $\log _{10}$ cfu/g & CON & POA1 & POA2 & SE & Linear $^{2}$ & Quadratic $^{2}$ \\
\hline E. coli & & & & & & \\
$\quad$ Farrowing & $5.67 \mathrm{a}$ & $4.93 \mathrm{~b}$ & $5.18 \mathrm{~b}$ & 0.10 & 0.008 & 0.001 \\
$\quad$ Weaning & $5.99 \mathrm{a}$ & $5.23 \mathrm{~b}$ & $5.33 \mathrm{~b}$ & 0.10 & 0.07 & 0.60 \\
Lactobacillus & & & & & & \\
Farrowing & $6.13 \mathrm{~b}$ & $7.49 \mathrm{a}$ & $7.34 \mathrm{a}$ & 0.07 & 0.02 & 0.92 \\
Weaning & $7.32 \mathrm{~b}$ & $7.75 \mathrm{a}$ & $7.81 \mathrm{a}$ & 0.06 & 0.001 & 0.14 \\
\hline
\end{tabular}

$\mathrm{SE}$ - standard error.

${ }^{1} \mathrm{CON}$ - basal diet; $\mathrm{POA} 1=\mathrm{CON}+0.1 \% \mathrm{POA} ; \mathrm{POA} 2=\mathrm{CON}+0.2 \% \mathrm{POA}$.

${ }^{2} \mathrm{CON}$ vs. POA1 vs. POA2.

$\mathrm{a}, \mathrm{b}$ - means in the same row with different letters differ $(\mathrm{P}<0.05)$. fermentation of carbohydrates and other fermentable material, predominantly in the large intestine of pigs. Acidifiers have received much attention in pig production due to their beneficial effects on growth performance of pigs (Papatsiros et al., 2011). In the case of early weaning, a sudden dietary change leads to digestive disturbances (Wu et al., 2012). The addition of organic acids to pig diets has been examined for decades, clearly demonstrating to improve growth performance and apparent total tract digestibility (Suryanarayana et al., 2012). Walsh et al. (2007)

Table 8 - Effect of dietary protected organic acid blend supplementation on faecal noxious gas emission in lactating sows ${ }^{1}$

\begin{tabular}{|c|c|c|c|c|c|c|}
\hline Item, $\%$ & $\mathrm{CON}$ & POA1 & POA2 & SE & Linear $^{2}$ & Quadratic $^{2}$ \\
\hline & \multicolumn{6}{|c|}{ Farrowing } \\
\hline \multicolumn{7}{|c|}{ Ammonia } \\
\hline $1 \mathrm{~d}$ & 3.8 & 3.8 & 4.8 & 0.6 & 0.3 & 0.5 \\
\hline $3 \mathrm{~d}$ & 4.3 & 3.8 & 3.3 & 0.9 & 0.4 & 1.0 \\
\hline $5 \mathrm{~d}$ & 2.8 & 3.8 & 3.0 & 0.5 & 0.7 & 0.2 \\
\hline $7 d$ & 0.5 & 1.0 & 1.5 & 0.6 & 0.2 & 1.0 \\
\hline \multicolumn{7}{|c|}{ Total mercaptans } \\
\hline $1 \mathrm{~d}$ & 0.8 & 0.6 & 0.5 & 0.2 & 0.5 & 1.0 \\
\hline $3 \mathrm{~d}$ & 0.8 & 1.3 & 0.8 & 0.3 & 1.0 & 0.2 \\
\hline $5 \mathrm{~d}$ & 0.5 & 0.6 & 0.6 & 0.3 & 0.7 & 0.6 \\
\hline $7 \mathrm{~d}$ & 0.4 & 0.3 & 0.4 & 0.2 & 1.0 & 0.7 \\
\hline \multicolumn{7}{|c|}{ Hydrogen sulphide } \\
\hline $1 \mathrm{~d}$ & $6.3 \mathrm{a}$ & $4.8 \mathrm{~b}$ & $3.3 \mathrm{c}$ & 0.6 & 0.01 & 1.0 \\
\hline $3 \mathrm{~d}$ & 9.5 & 7.8 & 8.3 & 1.4 & 0.5 & 0.5 \\
\hline $5 \mathrm{~d}$ & 4.8 & 4.8 & 6.5 & 1.5 & 0.4 & 0.6 \\
\hline $7 \mathrm{~d}$ & 5.3 & 4.0 & 4.0 & 1.0 & 0.4 & 0.6 \\
\hline \multicolumn{7}{|c|}{ Acetic acid } \\
\hline $1 \mathrm{~d}$ & 3.8 & 2.0 & 3.8 & 0.9 & 1.0 & 0.1 \\
\hline $3 \mathrm{~d}$ & 5.0 & 4.3 & 5.0 & 1.0 & 1.0 & 0.6 \\
\hline $5 \mathrm{~d}$ & 2.8 & 3.3 & 3.3 & 0.7 & 0.7 & 0.8 \\
\hline \multirow[t]{2}{*}{$7 \mathrm{~d}$} & 1.3 & 1.0 & 1.5 & 0.3 & 0.8 & 0.7 \\
\hline & \multicolumn{6}{|c|}{ Weaning } \\
\hline \multicolumn{7}{|c|}{ Ammonia } \\
\hline $1 \mathrm{~d}$ & $9.3 \mathrm{a}$ & $5.8 \mathrm{~b}$ & $6.0 \mathrm{~b}$ & 0.8 & 0.05 & 0.2 \\
\hline $3 \mathrm{~d}$ & 9.5 & 7.5 & 8.5 & 1.1 & 0.5 & 0.3 \\
\hline $5 \mathrm{~d}$ & $5.8 \mathrm{a}$ & $3.5 b$ & $3.3 b$ & 0.4 & 0.6 & 0.04 \\
\hline $7 \mathrm{~d}$ & 3.0 & 2.0 & 3.0 & 0.7 & 1.0 & 0.2 \\
\hline \multicolumn{7}{|c|}{ Total mercaptans } \\
\hline $1 \mathrm{~d}$ & 0.4 & 0.6 & 0.4 & 0.2 & 1.0 & 0.4 \\
\hline $3 \mathrm{~d}$ & 1.6 & 1.0 & 0.8 & 0.5 & 0.2 & 0.8 \\
\hline $5 \mathrm{~d}$ & 1.1 & 0.9 & 0.8 & 0.6 & 0.6 & 0.9 \\
\hline $7 \mathrm{~d}$ & 0.8 & 0.5 & 0.8 & 0.4 & 1.0 & 0.6 \\
\hline \multicolumn{7}{|c|}{ Hydrogen sulphide } \\
\hline $1 \mathrm{~d}$ & 18.8 & 15.8 & 16.8 & 5.4 & 0.8 & 0.7 \\
\hline $3 \mathrm{~d}$ & 17.0 & 14.0 & 12.5 & 2.7 & 0.3 & 0.8 \\
\hline $5 \mathrm{~d}$ & 6.5 & 7.0 & 7.8 & 1.6 & 0.7 & 1.0 \\
\hline $7 \mathrm{~d}$ & 1.0 & 1.0 & 3.0 & 0.8 & 0.1 & 0.4 \\
\hline \multicolumn{7}{|c|}{ Acetic acid } \\
\hline $1 \mathrm{~d}$ & 3.5 & 2.5 & 3.0 & 1.1 & 0.8 & 0.6 \\
\hline $3 \mathrm{~d}$ & 2.8 & 1.8 & 2.8 & 0.7 & 1.0 & 0.4 \\
\hline $5 \mathrm{~d}$ & 1.0 & 1.0 & 0.8 & 0.4 & 0.7 & 0.8 \\
\hline $7 \mathrm{~d}$ & 1.0 & 0.5 & 0.8 & 0.3 & 0.6 & 0.4 \\
\hline
\end{tabular}

$\mathrm{SE}$ - standard error.

${ }^{1} \mathrm{CON}-$ basal diet; POA $1=\mathrm{CON}+0.1 \%$ POA; POA $2=\mathrm{CON}+0.2 \% \mathrm{POA}$.

${ }^{2} \mathrm{CON}$ vs. POA 1 vs. POA2.

a,b,c - means in the same row with different letters differ $(\mathrm{P}<0.05)$. 
demonstrated that addition of $0.4 \%$ organic acid blend (fumaric, lactic, propionic, citric, and benzoic acids) to the diets of nursery pigs resulted in better growth rate, feed intake, and feed efficiency compared with the control diet. In the present study, there was no significant difference in the pre- and post-farrowing body weight and weaning body weight of sows. There was no difference in body weight loss among the dietary treatments during the lactating period of sows and nor was there any difference in the ADFI and backfat thickness loss during the experiments. Piglet survival, birth weight, and ADG were not affected by the dietary treatments. These results are in agreement with a study conducted by Canibe et al. (2005), who reported that ADG and ADFI were not affected, but the growth:feed ratio tends to be greater for growing pigs fed the diet containing 1.8\% formic acid. Feed additives such as enzymes, essential oils, and benzoic acid and their combination can improve growth performance in broiler chickens (Giannenas et al., 2014). Mohana Devi et al. (2014b) reported that supplementation of protein sources in growing pig diets improved the growth rate and feed intake. Dietary supplementation with medium-chain fatty acids together with probiotic in weaning pigs can improve growth performance, increase nutrient digestibility, and enhance biochemical profiles (Mohana Devi and Kim, 2014).

Mroz et al. (2000) suggested that organic acids had a beneficial effect on the apparent ileal and total tract digestibilities as well as calcium digestibility in growing pigs. This may be because of higher diet acidity due to the addition of organic acid to the diet. In agreement with this study, Partanen et al. (2007) demonstrated that dietary organic acid improved the apparent ileal digestibility in 34-kg pigs. In addition, the inclusion of soy bean in weaned piglet diets increased the microbial biodiversity in distal intestinal segments (Roca et al., 2014). Partanen et al. (2001) documented that formic acid tends to decrease bacterial nitrogen in different parts of the small intestine in pigs and improve apparent ileal digestibility of protein sources, certain essential amino-acids, lipids, calcium, and phosphorus.

In the present study, digestibility of $\mathrm{DM}, \mathrm{N}$, and energy were increased (linear effect, $\mathrm{P}<0.01$ ) by the dietary supplementation of $0.2 \%$ protected organic acid diets. The growth efficiency of market pigs was significantly increased by the addition of formic acid and this effect was further enhanced by the combination of formic acid with potassium sorbate (Partanen et al., 2002). Research implies an improved apparent ileal digestibility of protein and amino acids (Mroz et al., 1997) and an improved absorption of minerals (Jongbloed and Jongbloed, 1996).
Likewise, other previous reports with different types of organic acid indicated that the inclusion of organic acids such as $2 \%$ benzoic acid (Kluge et al., 2010) in the diet of lactating sows improved the digestibility of nutrients, and $0.5 \%$ phenyl lactic acid (Wang et al., 2009) improved nutrient digestibility in weaning pig and trends of nitrogen digestibility in growing pigs. Franco et al. (2005) also reported that combination of lactic acid with formic or fumaric acids numerically increased DM digestibility in weaning pigs. The increase in nutrient digestibility might have resulted from the increased microbial activity in the gastrointestinal tract (Yin et al., 2001). However, Kil et al. (2006) indicated that there was no positive response from nutrient digestibility with the inclusion of lactic, formic, or fumaric acids in weaning pigs.

As acidifiers, diets with organic acid improved growth performance (Partanen and Mroz, 1999), nutrient digestibility, gut health (Partanen et al., 2007; Wang et al., 2009), increased blood lymphocyte and WBC concentration, and decreased digesta $\mathrm{pH}$ value in the gastrointestinal tract (Ravindran and Kornegay, 1993) in pigs mainly due to its antibacterial and antifungal activities (Lavermicocca et al., 2003). In the present investigation, the WBC and lymphocyte of $0.2 \%$ protected organic acid were increased after sow weaning. Moreover, the $\mathrm{IgG}$ concentration of protected organic acid increased in sows after weaning. The supplementation of $0.2 \%$ protected organic acid in the diet of sucking piglets provided greater WBC counts and $\operatorname{IgG}$ concentration than the CON diet. Lymphocytes were more densely populated in the lamina propria and submucosa of caecal tonsil and ileum in diets supplemented with citric acid (0.5\%) (Chowdhury et al., 2009). In addition, a reduction in subclinical infections due to antimicrobial effects may contribute to improved nutrient digestibility and a reduction in the demand for nutrients by the gut-associated immune tissue.

It has been reported that addition of organic acids to pig diets alters the total microbial load, which can be particularly effective against $E$. coli and other acid-intolerant organisms (Dibner and Buttin, 2002). The presence of Lactobacillus in the gastrointestinal tract is believed to be beneficial for the pig. In the current study, the number of lactobacilli increased because of the inclusion of protected organic acid. Sows fed protected organic acid diets had decreased E. coli contents during farrowing and weaning period with a higher Lactobacillus concentration. Protected organic acid led to lower E. coli counts in the ileum and higher Lactobacillus counts in the colon, indicating that protected organic acid is more effective in retarding absorption of dietary acids and allowing more effective delivery of acids 
to the distal ileum, caecum, and colon of piglets (Bosi et al., 1999). Thus, including MCFA with organic acid blends would enhance its anti-microbial effects. Therefore, we hypothesised that the blends of different organic acids with MCFA in matrix coating could play an influential role in improving growth performance, meat quality, and microbial population of finishing pigs. However, E. coli population was significantly reduced in the faeces obtained from pigs fed diets supplemented with protected organic acid, which is in agreement with Li et al. (2008). In addition, Ahmed et al. (2014) stated that blends of organic acid supplementation reduce $E$. coli count and increase Lactobacilli population in weaned pigs.

Biagi et al. (2006) described a favourable effect of gluconic acid on intestinal microflora, morphology of intestinal villi, and general condition of piglets. Several studies documenting an improvement in growth efficiency have been reported in the literature (Missotten et al., 2009). The probable mode of actions of organic acids includes reducing the $\mathrm{pH}$ value of digesta in the gastrointestinal tract (Ravindran and Kornegay, 1993), regulating the balance of microbial populations in the gut, stimulating the secretion of digestive enzyme (Thaela et al., 1998), and promoting the growth and recovery of the intestinal morphology (Galfi and Bokori, 1990). According to Willamil et al. (2011), microencapsulated acids significantly modify caecal fermentation. Galfi and Bokori (1990) reported that sodium-butyrate supplementation in piglets reduced coliform bacteria and increased the number of Lactobacillus spp. in the ileum. In poultry, this supplementation also reduced coliform bacteria such as E. coli and Salmonella spp. (Van Immerseel et al., 2006). Our findings corroborate the above results by showing a significant increase in amounts of Lactobacillus with diets supplemented with coated protected organic acid. Besides, supplementation of $0.2 \%$ coated protected organic acid reduced the E. coli population in the excreta.

During recent years, different dietary strategies have been successfully assessed to reduce the gas emissions in piglet production. Cortus (2006) observed that urinary $\mathrm{pH}$ has a major impact on the volatilisation potential of $\mathrm{NH}_{3}$. As $\mathrm{pH}$ is reduced, the $\mathrm{NH}^{4+}$ concentration increases and $\mathrm{NH}_{3}$ concentration decreases within a solution. The $\mathrm{pH}$ of urine can be lowered by adding acidifying components to the diet, e.g., benzoic acid. These effects have been proven especially for pigs (Aarnink and Verstegen, 2007). Mean gas emissions of different dietary treatments are presented. The experimental diets with protected organic acid evaluated decreased $\mathrm{NH}_{3}$, Mercaptan, and hydrogen sulphide emission in the trial with respect to the control.
The most effective treatment was seen in the treatments with $0.1 \%$ and $0.2 \%$ protected organic acid compared with control diet. Effect of dietary protected organic acid on gas emission in weaning pigs shows some little difference but there was no significant difference observed among the treatments in weaning pigs. The faecal gas emission of sows was presented and the protected organic acid treatment had a lower $\mathrm{H}_{2} \mathrm{~S}$ than control treatment at the beginning of farrowing. Moreover, supplementation of protected organic acid treatment shows decreased (linear effect, $\mathrm{P}<0.04$ ) $\mathrm{NH}_{3}$ compared with that of CON treatment on days 1 and 5 in the weaning period. Faecal noxious gas emission in lactating sows did not display any significant difference between each treatment. It is possible that, with a higher proportion of protected organic acid blend, $\mathrm{NH}_{3}$, mercaptan, and hydrogen sulphide emission reduction would have been significant. According to Eriksen et al. (2010), 2\% benzoic acid supplementation in the diet of pigs reduced ammonia emissions by $60-70 \%$. The noxious bacterial metabolites and ammonia were reduced by acidifiers with the reduction in pathogen concentration (Dibner and Buttin, 2002). In our recent study, harmful gas emissions ( $\mathrm{RSH}$ and $\mathrm{H}_{2} \mathrm{~S}$ ) were influenced by the supplementation of dietary fibre and the addition of $5 \mathrm{~g} / \mathrm{kg}$ benzoic acid in the diet of growing pigs (Mohana Devi et al., 2015).

\section{Conclusions}

Dietary protected organic acids can actually become the most common and efficacious to improve health status and performance of pigs. Acidifying the diet with protected organic acid blend reduces the pathogenic bacterial load. It also improves nutrient digestibility, reduces fecal emission of ammonia and hydrogen sulphide, and increases beneficial bacterial counts. Best results are observed with inclusion of $0.02 \%$ organic acid blend. Thus, the use of organic acids in pig production could be a part of a general nutritional strategy focusing on better gastrointestinal health and productivity.

\section{Acknowledgments}

This work was carried out with the support of "Cooperative Research Program for Agriculture Science \& Technology Development (Project No. PJ009410)" Rural Development Administration, Republic of Korea.

\section{References}

Aarnink, A. J. A. and Verstegen, M. W. A. 2007. Nutrition, key factor to reduce environmental load from pig production. Livestock Science 109:194-203. 
Ahmed, S. T.; Hwang, J. A.; Hoon, J.; Mun, H. S. and Yang, C. J. 2014. Comparison of single and blend of acidifiers as an alternative to antibiotics on growth performance, faecal microflora and humoral immunity in weaned piglets. Asian Australasian Journal of Animal Sciences 27:93-100.

AOAC - Association of Official Analytical Chemists. 2000. Official methods of analysis.17th ed. Association of Official Analysis Chemistry. Gaithersburg, MD.

Ball, R. O. and Aherne, F. X. 1987. Influence of dietary nutrient density, level of feed intake and weaning age on young pigs. 2. Apparent nutrient digestibility and incidence and severity of diarrhoea. Canadian Journal of Animal Science 67:1105-1115.

Biagi, G.; Piva, A.; Moschini, M.; Vezzali, E. and Roth, F. X. 2006. Effect of gluconic acid on piglet growth performance, intestinal microflora, and intestinal wall morphology. Journal of Animal Science 84:370-378.

Bosi, P.; Jung, H. J.; Han, I. K.; Perini, S.; Cacciavillani, J. A.; Casini, L.; Creston, D.; Gremokolini, C. and Mattuzzi, S. 1999. Effects of dietary buffering characteristics and protected or unprotected acids on piglet growth, digestibility and characteristic of gut content. Asian Australasian Journal of Animal Sciences 7:1104-1110.

Budino, F. E. L.; Thomaz, M. C.; Kronka, N.; Nakaghi, L. S. O.; Tucci, F. M.; Fraga, A. L.; Scandolera, A. J. and Huaynate, R. A. R. 2005. Effect of probiotic and prebiotic inclusion in weaned piglet diets on structure and ultra-structure of small intestine. Brazilian Archives of Biology and Technology 6:921-929.

Canibe, N.; Hojberg, O.; Hojsgaard, S. and Jensen, B. B. 2005. Feed physical form and formic acid addition to the feed affect the gastrointestinal ecology and growth performance of growing pigs. Journal of Animal Science 83:1287-1302.

Chowdhury, R.; Islam, K. M. S.; Khan, M. J.; Karim, M. R.; Haque, M. N.; Khatun, M. and Pesti, G. M. 2009. Effect of citric acid, avilamycin and their combination on the performance, tibia ash and immune status of broilers. Poultry Science 88:1616-1622.

Cortus, E. L. 2006. A dynamic model of ammonia production within grow-finish barns. PhD thesis. University of Saskatchewan. Department of Bioresource Engineering. Saskatoon, Canada.

Costa, L. B.; Berenchtein, B.; Almeida, V. V.; Tse, M. L. P.; Braz, D. B.; Andrade, C.; Mourao, G. B. and Miyada, V. S. 2011. Phytogenic additives and sodium butyrate as growth promoters of weaned piglets. Archivos de Zootecnia 60:687-698.

Dibner, J. J. and Buttin, P. 2002. Use of organic acid as a model to study the impact of gut microflora on nutrition and metabolism. Journal of Applied Poultry Research 11:453-463.

Eriksen, J.; Adamsen, A. P.; Norgaard, J. V.; Poulsen, H. D.; Jensen, B. B. and Petersen, S. O. 2010. Emissions of sulphur-containing odorants, ammonia, and methane from pig slurry: Effects of dietary methionine and benzoic acid. Journal of Environmental Quality 39:1097-1107.

Franco, L. D.; Fondevila, M.; Lobera, M. B. and Castrillo, C. 2005. Effect of combinations of organic acids in weaned pig diets on microbial species of digestive tract contents and their response on digestibility. Journal of Animal Physiology and Animal Nutrition 89:88-93.

Galfi, P. and Bokori, J. 1990. Feeding trial in pigs with a diet containing sodium n-butyrate. Acta Veterinaria Hungarica 38:3-17.

Giannenas, I. A.; Papaneophytou, C. P.; Tsalie, E.; Tritafillou, E.; Tontis, D. and Kontopidis, G. A. 2014. The effect of benzoic acid and essential oil compounds in combination with protease on the performance of chickens. Journal of Animal and Feed Sciences 23:73-81.

Hart, G. K. and Dobb, G. J. 1988. Effect of a faecal bulking agent on diarrhoea during enteral feeding in the critically ill. Journal of Parenteral and Enteral Nutrition 12:465-468.

Jensen, B. B.; Hojberg, O.; Mikkelsen, L. L.; Hedemann, S. and Canibe, N. 2003. Enhancing intestinal function to treat and prevent intestinal disease. p.103-119. In: Proceedings of the 9th International Symposium on Digestive Physiology in Pigs, Banff, Canada.

Jongbloed, A. W. and Jongbloed, R. 1996. The effect of organic acids in diets for growing pigs on enhancement of microbial phytase efficacy. ID-DLO Report no. 96009. Institute for Animal Science and Health, Lelystad, The Netherlands.

Kil, D. Y.; Piao, L. G.; Long, H. F.; Lim, J. S.; Yun, M. S.; Kong, C. S.; Ju, W. S.; Lee, H. B. and Kim, Y. Y. 2006. Effects of organic or inorganic acid supplementation on growth performance, nutrient digestibility and white blood cell counts in weanling pigs. Asian Australasian Journal of Animal Sciences 19:252-261.

Kluge, H.; Broz, J. and Eder, K. 2006. Effect of dietary benzoic acid on urinary $\mathrm{pH}$ and nutrient digestibility in lactating sows. Livestock Science 134:119-121.

Koyuncu, S.; Anderssen, M. G.; Charlotta, L.; Skandamis, P. N.; Gounadaki, A.; Zentek, J. and Haggblom, P. 2013. Organic acids for control of Salmonella in different feed materials. BMC Veterinary Research 9:81-89.

Lavermicocca, P. F.; Valerio, V. and Visconti, A. 2003. Antifungal activity of phenyl lactic acid against molds isolated from bakery products. Applied and Environmental Microbiology 69:634-640.

Li, Z.; Yi, G.; Yin, J.; Sun, P.; Li, D. and Knight, C. 2008. Effects of organic acids on growth performance, gastrointestinal $\mathrm{pH}$, intestinal microbial populations and immune responses of weaned pigs. Asian Australasian Journal of Animal Sciences 21:252-261.

Missotten, J. A. M.; Goris, J.; Michiels, J.; Van Coillie, E.; Herman, L.; De Smet, S.; Dierick, N. A. and Heyndrickx, M. 2009. Screening of isolated lactic acid bacteria as potential beneficial strains for fermented liquid pig feed production. Animal Feed Science and Technology 150:122-138.

Mohana Devi, S.; Balachandar, V.; Lee, S. I. and Kim, I. H. 2014a. An outline of meat consumption in the Indian population - A pilot review. Korean Journal for Food Science of Animal Resources 34:507-515.

Mohana Devi, S.; Devi, U. S. and Kim, I. H. 2014b. Evaluation of dietary sources of protein on growth performance in pigs. Veterinarni Medicina 59:247-253.

Mohana Devi, S. and Kim, I. H. 2014. Effect of medium chain fatty acids (MCFA) and probiotic (Enterococcus faecium) supplementation on the growth performance, digestibility and blood profiles in weanling pigs. Veterinarni Medicina 59:527-535.

Mohana Devi, S.; Cheong, J. Y. and Kim, I. H. 2015. Effects of dietary fiber and benzoic acid on growth performance, nutrient digestibility, reduction of harmful gases, and lipid profiles in growing pigs. Annals of Animal Science 15:463-474.

Montagne, L.; Cavaney, F. S.; Hampson, D. J.; Lalles, J. P. and Pluske, J. R. 2004. Effect of diet composition on postweaning coli-bacillosis in piglets. Journal of Animal Science 82:2364-2374.

Mroz, Z. 2005. Organic acids as alternatives to antibiotic growth promoters for pigs. p.169-182. In: Advances in pork production. Foxcroft, G., ed. University of Alberta Press, Edmonton, Alberta.

Mroz, Z.; Jongbloed, A. W.; Partenen, K.; van Diepen, J. T.; Kemme, H. M. and Kogut, P. A. 1997. Apparent digestibility of amino acids and balance of nitrogen and minerals as influenced by buffering capacity and organic acids in diets for growing swine. Journal of Animal Science 75(Suppl. 1):185 Abst.

Mroz, Z.; Jongbloed, A. W.; Partanen, K. H.; Vreman, K.; Kemme, P. A. and Kogut, J. 2000. The effects of calcium benzoate in diets with or without organic acids on dietary buffering capacity, apparent digestibility, retention of nutrients and manure characteristics in swine. Journal of Animal Science 78:2622-2632.

Mroz, Z.; Koopmans, S. J.; Bannink, A.; Partanen, A. K.; Krasucki, W.; Overland, M. and Radcliffe, S. 2006. Carboxylic acids as bioregulators and gut growth promoters in non-ruminants. p.81-133. 
In: Biology of nutrition in growing animals. v.4. Mosenthin, R.; Zentek, J. and Zebrowska, T., eds. Elsevier Limited, London.

NRC - National Research Council. 2012. Nutrient requirements of swine. 11th ed. National Academy Press, Washington, DC.

Overland, M.; Kjos, N. P.; Borg, M.; Skjerve, E. and Sorum, H. 2008. Organic acids in diets for entire male pigs: Effect on skatole level, microbiota in digesta, and growth performance. Livestock Science 115:169-178.

Papatsiros, V. G.; Tassis, P. D.; Tzika, E. D.; Papaioannou, D. S.; Petridou, E.; Alexopoulos, C. and Kyriakis, S. C. 2011. Effect of benzoic acid and combination of benzoic acid with probiotic containing Bacillus cereus var. Toyoi in weaned pig nutrition. Polish Journal of Veterinary Sciences 14:117-125.

Partanen, K.; Jalava, T.; Valaja, J.; Perttila, S.; Siljander-Rasi, H. and Lindeberg, H. 2001. Effect of dietary carbadox or formic acid and fibre level on ileal and faecal nutrient digestibility and microbial metabolite concentrations in ileal digesta of the pig. Animal Feed Science and Technology 93:137-155.

Partanen, K.; Siljander-Rasi, H.; Alaviuhkola, T.; Suomi, K. and Fossi, M. 2002. Performance of growing-finishing pigs fed medium or high fibre diets supplemented with avilamycin, formic acid or formic acid-sorbate blend. Livestock Production Science 73:139-152.

Partanen, K.; Siljander-Rasi, H.; Pentikainen, J.; Pelkonen, S. and Fossi, M. 2007. Effects of weaning age and formic acid-based feed additives on pigs from weaning to slaughter. Archives of Animal Nutrition 61:336-356.

Partanen, K. H. and Mroz, Z. 1999. Organic acids for performance enhancement in pig diets. Nutrition Research Reviews 12:117-145.

Ravindran, V. and Kornegay, E. T. 1993. Acidification of weaner pig diets: A review. Journal of the Science of Food and Agriculture 62:313-322.

Roca, M.; Nofrarias, M.; Majo, N.; de Rozas, A. M. P.; Segales, J.; Castillo, M.; Martin-Orue, S. M.; Espinal, A.; Pujols, J. and Badiola, I. 2014. Changes in bacterial population of gastrointestinal tract of weaned pigs fed with different additives. BioMed Research International v.2014, article ID 269402, 13p. doi: 10.1155/2014/269402.

Suryanarayana, M. V. A. N.; Suresh, J. and Rajasekhar, M. V. 2012. Organic acids in swine feeding - A Review. Agricultural Science Research Journal 2:523-533.

Thaela, M. J.; Jensen, M. S.; Pierzynowski, S. G.; Jakob, S. and Jensen, B. B. 1998. Effect of lactic acid supplementation in pigs after weaning. Journal of Animal and Feed Sciences 7:181-183.
Van Immerseel, F.; Russell, J. B. and Flythe, M. D. 2006. The use of organic acids to combat Salmonella in poultry: a mechanistic explanation of the efficacy. Avian Pathology 35:182-188.

Walsh, M. C.; Sholly, D. M.; Hinson, R. B.; Saddoris, K. L.; Sutton, A. L.; Tadcliffe, J. S.; Odgaard, R.; Murphy, J. and Richert, B. T. 2007. Effects of water and diet acidification with and without antibiotics on weanling pig growth and microbial shedding. Journal of Animal Science 85:1799-1808.

Wang, J. P.; Yoo, J. S.; Lee, J. H.; Jang, H. D.; Kim, H. J.; Shin, S. O.; Seong, S. I.; and Kim, I. H. 2009. Effect of phenyllactic acid on growth performance, nutrient digestibility, microbial shedding and blood profiles in pigs. Journal of Animal Science 87:3235-3243.

Willamil, J.; Creus, E.; Francisco Perez, J.; Mateu, E. and Martin-Orue, S. M. 2011. Effect of a microencapsulated feed additive of lactic acid and formic acid on the prevalence of Salmonella in pigs arriving at the abattoir. Archives of Animal Nutrition 65:431-444.

Williams, C. H.; Iismaa, O. and David, D. J. 1962. Determination of chromic oxide in faeces samples by atomic absorption spectrophotometry. The Journal of Agricultural Science 59:381.

Wu, X.; Zhang, Y.; Liu, Z.; Li, T. J. and Yin, Y. L. 2012. Effects of oral supplementation with glutamate or combination of glutamate and N-carbamylglutamate on intestinal mucosa morphology and epithelium cell proliferation in weanling piglets. Journal of Animal Science 90:337-339.

Yan, L.; Hong, S. M. and Kim, I. H. 2012. Effect of bacteriophage supplementation on the growth performance, nutrient digestibility, blood characteristics, and fecal microbial shedding in growing pigs. Asian-Australasian Journal of Animal Sciences 25:1451-1456.

Yan, L. and Kim, I. H. 2013. Effects of dietary supplementation of fermented garlic powder on growth performance, apparent total tract digestibility, blood characteristics and faecal microbial concentration in weanling pigs. Journal of Animal Physiology and Animal Nutrition 97:457-464.

Yin, Y. L.; Baidoo, S. K.; Schulze, H. and Simmins, P. H. 2001. Effects of supplementing diets containing hulless barley varieties having different levels of non-starch polysaccharides with $\beta$-glucanase and xylanase on the physiological status of the gastrointestinal tract and nutrient digestibility of weaned pigs. Livestock Production Science 71:97-107.

Zhao, P. Y.; Jung, J. H. and Kim, I. H. 2012. Effect of mannan oligosaccharides and fructan on growth performance, nutrient digestibility, blood profile, and diarrhoea score in weanling pigs. Journal of Animal Science 90:833-839. 